\title{
ANALYSIS OF LANDSCAPE PAINTINGS TO HIGHLIGHT THE IMPORTANCE OF FOREST ECOSYSTEM SERVICES IN LATVIA
}

\author{
Ilze Pauliṇa, Zane Lībiete \\ Latvian State Forest Research Institute 'Silava', Latvia \\ paulina.ilze@gmail.com
}

\begin{abstract}
Forests and woodlands provide a wide variety of ecosystem services that are usually classified within three categories: provisioning services, regulating (supporting) services and cultural services. While provisioning and regulating services are widely analysed, there is a lack of information about the cultural ecosystem services, particularly some sub-categories of these. In this study, we have focused on inspiration for creativity as a sub-category of cultural ecosystem services provided by forests and analysed the depiction of forest ecosystems in landscape paintings of Latvian artists. It may be concluded that forest ecosystems serve as an important source of inspiration for creativity and art, as may be seen in the landscape paintings of Latvian artists of the $20^{\text {th }}$ century. Characteristic landscape features of birth and living places of the artists are reflected in their works. The performed analysis is the first of its kind in Latvia, and it may be further expanded, either by incorporating other aspects of creativity or adding economic dimension, for example, by surveying the art market.
\end{abstract}

Key words: Forest ecosystems, cultural ecosystem services, inspiration, creativity, landscape paintings.

\section{Introduction}

Forests and woodlands are multifunctional ecosystems and providers of multiple ecosystem services. The multifunctional and multiservice purpose of the world's forests is identified in the United Nations Forest Principles (1992), stating that 'forest resources and forest land shall be managed and used sustainably to fulfil social, economic, ecological, cultural and spiritual needs of present and future generations'. This definition is very similar to the one given in the Latvian Law on Forests (2000). The diverse services provided by forests include provisioning, regulating, cultural and supporting services (Shvidenko et al., 2005; The Economics of Ecosystems and Biodiversity, 2010) or, in the Common International Classification of Ecosystem Services (CICES system), referred to as provisioning, regulation \& maintenance and cultural services (Haines-Young \& Potschin, 2018). Regardless of the classification system, cultural ecosystem services are recognized in all of them, and form an important and irreplaceable aspect of nature's contribution to people's welfare (Figure 1).

Cultural ecosystem services are recognized as an essential part of the contribution of nature to human welfare (Millenium Ecosystem Assessment, 2005), but at the same time there is very little information available concerning several categories of these services, including inspirational services. This fact is largely related to the difficulties that arise from attempts to describe and assign value to ecosystem services that provide no clear and direct material benefits. Even though it is clear that nature has a strong impact on culture and that natural and cultivated ecosystems inspire a wide spectrum of cultural expressions, scientific literature on this topic is scarce.

Millenium Ecosystem Assessment distinguishes five main types of inspirational services, namely, verbal art and writings that are inspired by nature, the performing arts, fine arts, design and fashion and the media in general. Nature is used as a source of inspiration in many literary works, it has influenced dance, song and theatre, a number of examples relate to the portrayal of different ecosystems in paintings, sculptures and works of craft, the beauty of the natural world has been largely reproduced in items of utilitarian use, and nature is widely used by various types of media to make programs and sell products (De Groot et al., 2005).

In the Baltic and Nordic countries, forests are among the dominant terrestrial ecosystems, and they have largely influenced people's welfare by providing them with necessary resources, both directly and indirectly, through regulating the climate. At the same time, landscape has much more to offer than purely utilitarian values, and dominant ecosystems have doubtlessly shaped also the cultural identity of the inhabitants of the region. In Latvia, forests comprise more than a half of total land area (Ministry of Agriculture Republic of Latvia, 2019), and forest ecosystems have traditionally been of high importance in multiple ways. Apart from analysing traditional uses, significant landscape-scale studies have been conducted recently, pertaining to the ecological succession of forests and the importance of landscape diversity in reducing insect damage (e.g., Baders et al., 2017; Bāders et al., 2018a), but the information on the importance of dominant landscape types in the context of cultural ecosystem services remains scarce at best and non-existent at worst (depending on the sub-category of the investigated ecosystem service).

In this study, we have focused on a specific subcategory of ecosystem services, namely, inspiration for art. We have analysed how forest ecosystems have influenced the landscape paintings created in Latvia. 


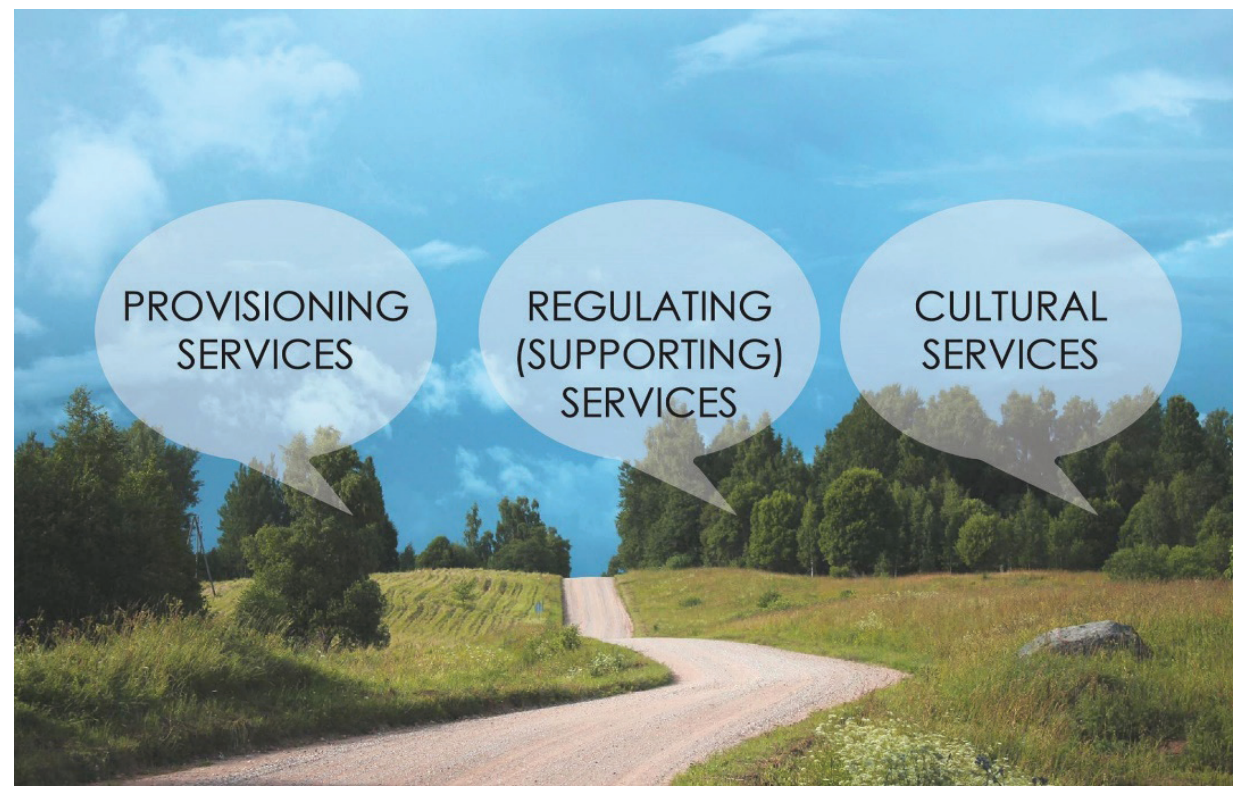

Figure 1. Ecosystem service groups as recognized by the main classification systems.

The aim of the study was twofold: 1) to identify the most important types of forest ecosystems for artistic inspiration, and 2) to establish whether the forest cover and landscape in the regions where the artists have worked have correlation with the emergence of landscape paintings with forest.

\section{Materials and Methods}

To evaluate the importance of different types of forest ecosystems and their elements as inspiration for art in Latvia, assessment of landscape paintings of Latvian artists was performed. We used two data sets: 1) The funds of the Artists' Union of Latvia (in total 512 paintings created during the $20^{\text {th }}$ and $21^{\text {st }}$ century); 2) Web-based available information from the artwork auction houses (in total 3131 paintings, auctioned since 2005 , mainly from the $20^{\text {th }}$ and $21^{\text {st }}$ century, but a few paintings from the end of the $19^{\text {th }}$ century as well). The websites of the auction houses contain photos of the paintings; therefore, it is possible to carry out visual assessment. Initially, 10 categories for the classification of all paintings were selected, namely: 1) no forest or forest elements; 2) pine (Pinus sylvestris L.) forest; 3) spruce (Picea abies (L).Karst.) forest; 4) birch (Betula spp.) forest; 5) mixed coniferous forest; 6) mixed deciduous forest; 7) mixed forest; 8) wetland forest; 9) forests with unidentified tree species; 10) forest fragments/elements in a different type of landscape. The number of the categories was further reduced, to ensure sufficient representation of forest landscapes in each group, and six categories were included in further analysis: 1) no forest or forest elements; 2) coniferous forest (pine, spruce and mixed conifer forests combined); 3) deciduous forest (birch and mixed conifer forest combined); 4) mixed forest; 5) forest with unidentified tree species; 6) forest fragments/elements in a different type of landscape. Wetland forest was excluded from further analysis due to very low representation. A basic statistical analysis was carried out to identify the most common forest landscapes in the paintings.

To evaluate, whether the forest cover in the country has had an impact on the willingness of the artists to picture this specific ecosystem, we correlated the available data on the forest cover (Kronitis, 1965; Bāders et al., 2018b) with the number of landscape paintings where different types of forests occur (mean values of decades). In this case, we omitted the paintings with only forest fragments but focused on those where forest was the dominant type of portrayed landscape. Complete set of data on both the forest cover in Latvia and number of respective paintings from the studied databases was available for the period from the 1900ties to 1990ties, therefore we used this specific timeframe.

To evaluate whether and how the creative work of the painters has been inspired by the dominant landscape of his birth and work place, we analysed the available information from the biographies of the painters that were included in our databases. The regions we used were following: 1) Rīga; 2) Rīga vicinity; 3) Latgale; 4) Zemgale; 5) Vidzeme; 6) Kurzeme; 7) unknown.

\section{Results and Discussion}

On average, pictures with forest landscapes or forest elements constituted $19 \%$ of the total number of all analysed paintings (the complete data set, covering the available records from the $20^{\text {th }}$ and $21^{\text {st }}$ century), the percentage being rather similar for both assessed 

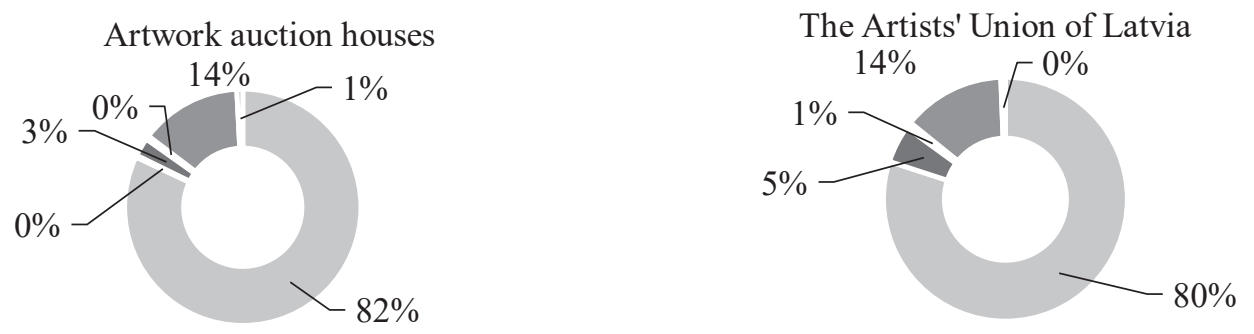

Both data sets combined

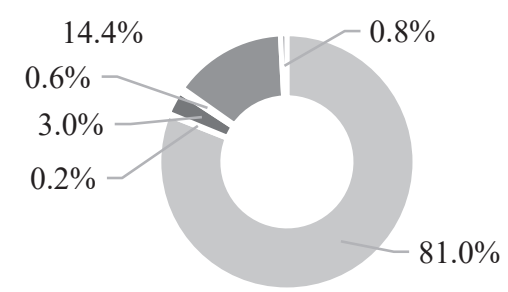

Figure 2. Occurrence of forest ecosystems and forest elements in the assessed paintings. Legend: Paintings without forest of forest elements; - Paintings with coniferous forest; - Paintings with forests with unidentified tree species; - Paintings with deciduous forest; - Paintings with forest fragment/elements in different kind of landscape; - Paintings with mixed forest.

data sets $(18 \%$ for the paintings from the auction houses and $20 \%$ for the paintings from the funds of the Artist's Union of Latvia). Also the percentage of paintings with forest fragments or forest elements was very similar for both datasets, on average constituting $76 \%$ of all paintings where forest landscape or elements were depicted at all. The next most common category was forest with unidentified tree species, followed by mixed forest, deciduous forest and coniferous forest $(16 \%, 4 \%, 3 \%$ and $1 \%$ of all paintings with forest landscape or element, respectively) (Figure 2).

The representation of different forest types in the paintings reflect both the characteristics of the forest landscape of Latvia formed by relatively small stands (according to the official data of Latvian Forest Register, 2018, an average size of the forest compartment in Latvia is $1.26 \pm 1.46 \mathrm{ha}$ ) with a patchwise pattern of coniferous and deciduous forests, and also the aesthetic perception of the artists, preferring more colourful and irregular mixed or deciduous stands to relatively uniform and homogeneous conifer forests.

Forest fragments or forest elements are often used as a background or as an accent in paintings of other types of landscapes, to balance out the composition.

In Latvia, the forest cover has gradually increased throughout the $20^{\text {th }}$ century, from $26 \%$ in 1920 to $44 \%$ in 1990. Ownership and land use structure changed

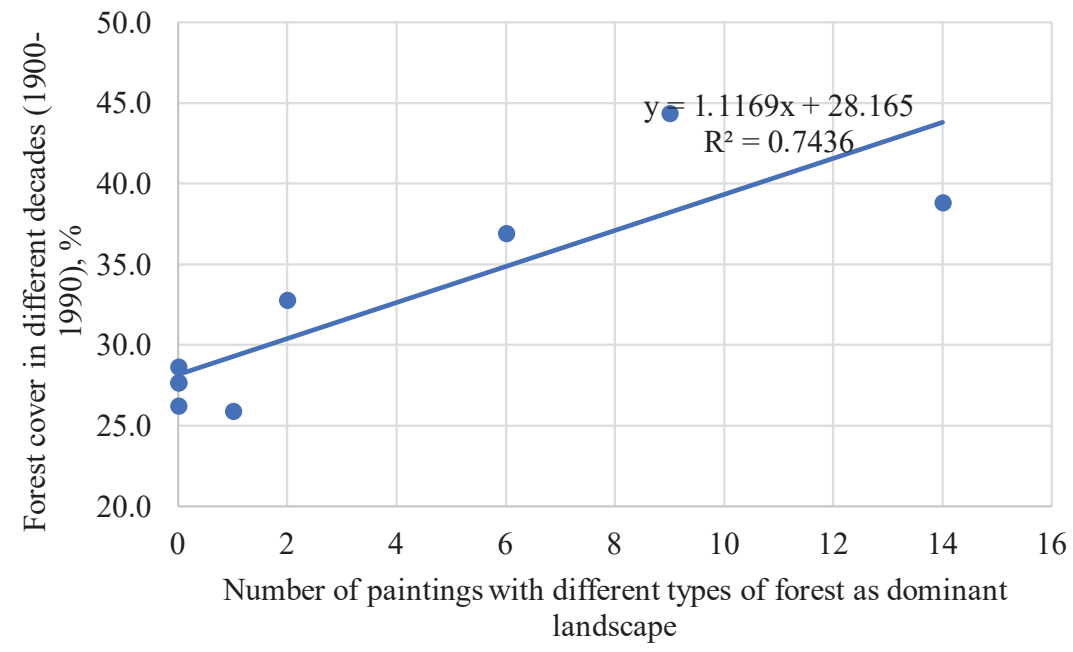

Figure 3. Correlation between forest cover and occurrence of forest depiction in the landscape paintings. 
Table 1

Birthplaces of the analysed landscape painters (data set of the Artists' Union of Latvia; n=175)

\begin{tabular}{|l|c|c|c|c|c|c|c|}
\hline & Rīga & Rīga vicinity & Latgale & Zemgale & Vidzeme & Kurzeme & Unknown \\
\hline Number of artists & 51 & 14 & 12 & 18 & 36 & 22 & 22 \\
\hline Proportion, \% from the total & 29.1 & 8.0 & 6.9 & 10.3 & 20.6 & 12.6 & 12.6 \\
\hline
\end{tabular}

after the WWI and proclamation of independence; forests mostly remained in state ownership but agricultural lands became private. During the 1930s, state policy promoted the afforestation of some agricultural areas, as farmers needed wood and timber and it was also thought that an increase of forest area would increase the export (Bells \& Nikodemus, 2000). We found a positive correlation between the forest cover in Latvia and the number of paintings showing different types of forest; the correlation coefficient $\mathrm{R}=0.85$ indicates close linear relationship, and the model is statistically significant, with $\mathrm{p}=0.007$ (Figure 3 ). Caution is, however, needed in the interpretation

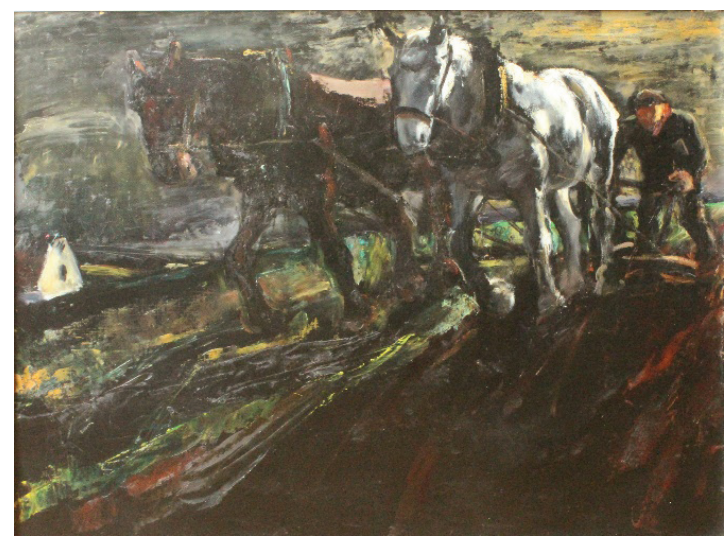

1. 20 years ago (1965).

Ģederts Eliass, Zemgale

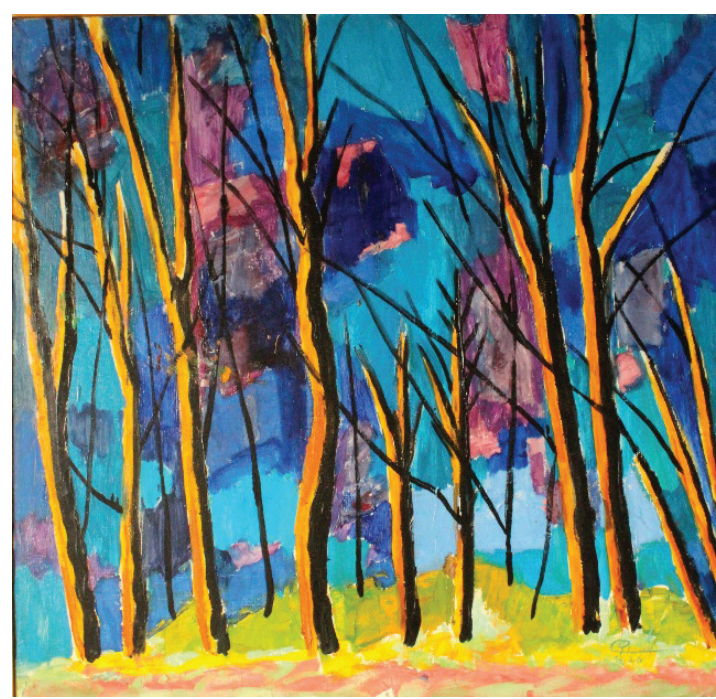

3. Autumn (1976). Rūdolfs Pinnis, Vidzeme of these results, as also other factors apart from the forest cover may have influenced this, for example, the increasing number of artists in general. In any case this may at least be considered as a significant trend, and obtained results indirectly confirm the importance of forest ecosystems as the source of inspiration for art.

More than one third of the analysed painters (65) were born in Rīga or Rīga vicinity. From other regions, Vidzeme was represented by the highest number of artists (Table 1). Part of them came from towns or cities, but in the rural areas, small towns are often located in a close proximity to forests, therefore, it may be assumed that the artists had a close connection

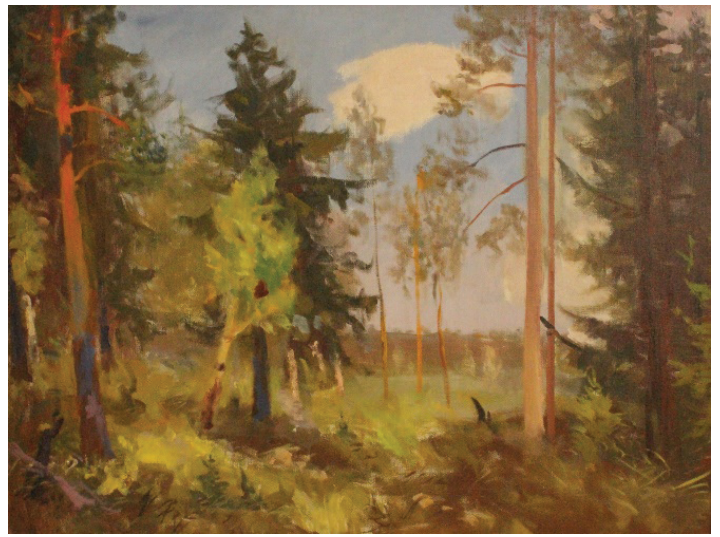

2. Sunny day in the forest (1962). Kārlis Miesnieks, Vidzeme

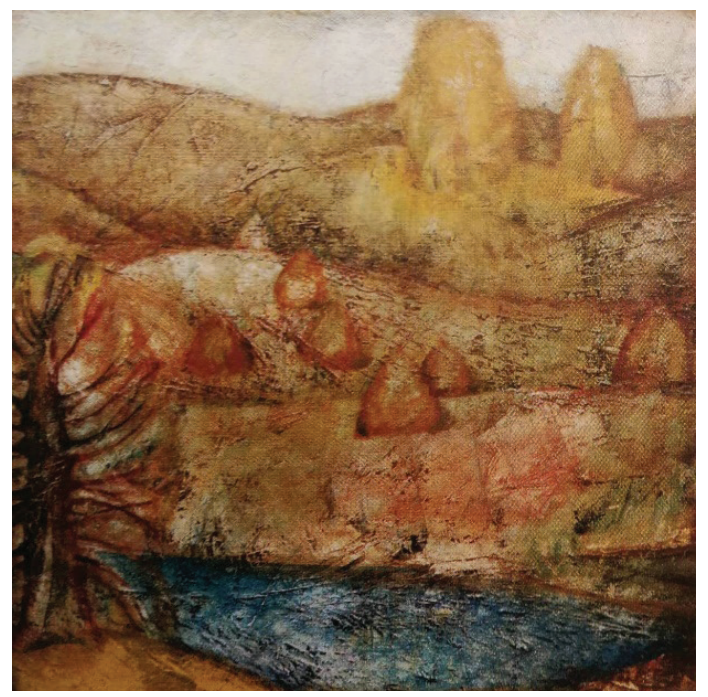

4. Autumn (1968). Jāzeps Pīgoznis, Latgale

Figure 4. Examples of landscape depiction in the paintings of Latvian artists of the $20^{\text {th }}$ century. 
to natural ecosystems. Even though, in the $20^{\text {th }}$ century the places of residence of many artists have been varying, regardless of their places of birth due to complicated political situation, we may assume (also biographies of the artists confirm this) that many painters have spent most of their lives in their native regions. From the analysed data, it is not possible to conclude whether urban or rural environment has influenced their creative work. Regardless of the painters' places of birth - the capital or smaller towns - they have spent a lot of time in nature, painting in the plain air.

Below are given four examples of different rural landscapes painted by four Latvian artists; born in different regions of Latvia (Figure 4), and it is possible to distinguish some characteristic regional differences of landscape in their works of art.

Landscape No. 1 was painted by Ģederts Eliass (1887-1975), born in the rural district of Platone, Jelgava municipality, Zemgale region. Representative of realistic painting, he has worked in the scope of different genres. The presented example shows farmers working within a setting of a typical rural landscape of the Zemgale region. Zemgale is located in the southern part of Latvia, both now and historically it has the largest share of agricultural land and comparatively low forest cover.

The author of painting No. 2 is Kārlis Miesnieks (1887-1977). He was born in the rural district of Jaunpiebalga, Vidzeme region. Representative of the realistic painting, he has painted still lives, landscapes, genre paintings, portraits. The artist was born in Vidzeme, characterized with large forest areas. The painted landscape may be considered as rather typical for the region.

Landscape No. 3 is the work of Rūdolfs Pinnis (1902-1992). He was born in Madona, Vidzeme region. One of the best known and most popular Latvian artists, Rūdolfs Pinnis is the representative of fauvism style in Latvian painting. His works are full of dynamics and expression, saturated with colours. Many of his works show forest ecosystems, and even though it is hardly possible to distinguish the specific tree species or forest types due to the style he used, it may be assumed that the environment where the artist was born and lived had largely influenced his creativity.

The author of painting No. 4 is Jāzeps Pīgoznis (1934-2014). He was born in Silmala rural district, Latgale region. The artist was versatile in his creativity. Lakes, hills and small patches of forest are characteristic features of Latgale region, and these may be distinguished in the given example as well.

Certainly, the examples presented above are largely based on assumptions; the biographies of the artists are not always complete, often due to difficult political and economic situation in the $20^{\text {th }}$ century. The personal style of each painter has influenced how nature was portrayed, and in many cases it was not possible to perform a more detailed analysis of the forest types. Still, these assumptions may certainly be considered as trends, and they provide an insight and an illustration of how the natural ecosystems supply cultural ecosystem services, namely, inspiration for the creativity. This study has confirmed, both directly and indirectly, that dominant ecosystems of a certain area, in this case - forests, are of high importance when shaping the cultural identity and, within it, creative expression of its residents (Figure 5). It has also indicated that works of art may be used to better understand and illustrate the importance of certain ecosystem types or their elements in sustaining and inspiring creativity. Through the paintings and other works of art, artists pass on their perception of the surrounding world and its values, thus enriching the cultural experience of others.

It has to be understood that culture is a complicated phenomenon that includes both tangible and intangible aspects, and the latter are very often lived or experienced rather than described or evaluated (Satterfield et al., 2013). Still, attempts to quantify the intangible services are important, for these provide tools that allow including additional aspects in the planning of ecosystem management and are much needed to consider the multifunctional nature of the provided ecosystem services. A study on the inspirational value of ecosystems in popular music was performed by Coscieme (2015), and

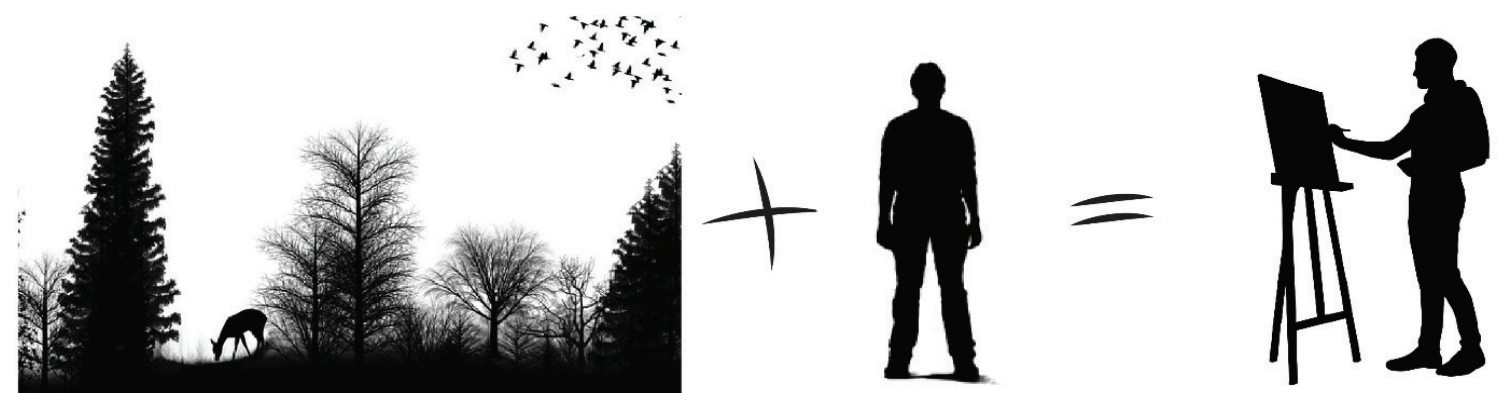

Figure 5. Natural ecosystems as inspiration for creativity. 
performing the analysis of the digital sector of the music industry, the author concluded that ecosystems have contributed $\$ 0.6$ billion to the music industry in the time period of 10 years. Interestingly, one of the most important ecosystems in this regard was tropical forest ecosystem.

This kind of study, where the occurrence of a certain type of landscape has been analysed to attempt to quantify the significance of the given ecosystem in provision of cultural (inspirational) ecosystem services, is rare and, to the author's knowledge, the first of this kind in the Baltic region. It may be further expanded and detailed, both including additional aspects of creativity that are influenced by landscape and ecosystems and also by performing a more detailed analysis in the same direction, including analysis, for example, of the art market, thus striving to assign the studied ecosystem service monetary value.

\section{Conclusions}

1. The relatively high percentage of paintings with forest landscape or forest elements (almost one fifth from all the studied pictures) confirm the importance of forest ecosystems in the provision of cultural ecosystem services, namely, as inspiration for art in Latvia.
2. The most common representation of forest in the paintings is through forest elements or forest fragments in a different kind of landscape, so as to balance out the composition and accentuate the general theme. Forests with unidentified tree species and mixed forests come next in occurrence.

3. The number of paintings of forest ecosystems increase with increasing forest cover in Latvia during the 20th century. The relatively short distances and good accessibility enable also the artists from urban areas to go out in the plain air in the forest environment.

4. The characteristic landscape features of the birthplaces and working places of Latvian landscape painters are to some extent mirrored in their works and may have influenced their creativity.

\section{Acknowledgements}

The study was in part carried out within the frames of Latvia State Forest Research Institute 'Silava' and JSC 'Latvia's State Forests' collaboration research programme No. 5-5.5_006_101_16_6 'The impact of forest management on ecosystem services provided by forests and related ecosystems'.

\section{References}

1. Bells, S., \& Nikodemus, O. (2000). Rokasgrāmata meža ainavas plānošanai un dizainam (Manual for planning and design of forest landscape). Rīga: a/s 'McĀbols' 75 lpp. (in Latvian)

2. Bāders, E., Jansons, Ā., Matisons, R., Elferts, D., \& Desaine, I. (2018a). Landscape diversity for reduced risk of insect damage: a case study of Spruce bud Scale in Latvia. Forests, 9, 545, DOI: 10.3390/f9090545.

3. Bāders, E., Lūkins, M., Zariņš, J., Krišāns, O., Jansons, Ā., \& Jansons, J. (2018b). Recent land cover changes in Latvia. In: Proceedings of $24^{\text {th }}$ Annual International Scientific Conference 'Research for Rural Development 2018', 16-18 May 2018 Jelgava, Latvia, Vol. 1, 34-39.

4. Baders, E., Senhofa, S., Purina, L., \& Jansons, A. (2017). Natural succession of Norway spruce stands in hemiboreal forests: case study in Slitere national park, Latvia. Baltic Forestry, 23(2), 522-528.

5. Bells, S., \& Nikodemus, O. (2000). Rokasgrāmata meža ainavas plānošanai un dizainam (Manual for planning and design of forest landscape). Rīga: a/s 'McĀbols', 75 lpp. (in Latvian)

6. Coscieme, L. (2015). Cultural ecosystem services: The inspirational value of ecosystems in popular music. Ecosystem Services 16, 121-124.

7. De Groot, R., Ramakrishnan, P.S., Van de Berg, A., Kulenthran, T., Muller, S., Pitt, D., Wascher, D., Wijesuriya, G., Amelung, B., Eliezer, N., Gopal, A.R., \& Rössler, M. (2005). Cultural and Amenity Services. In: Ecosystems and Human Well-being: Current State and Trends, Vol. 1, Island Press, pp. 455476.

8. Haines-Young, R., \& Potschin, M.B. (2018). Common International Classification of Ecosystem Services (CICES) V5.1 and Guidance on the Application of the Revised Structure. Retrieved February 10, 2019, from www.cices.eu.

9. Kronītis, J. (1965). Latvijas mežu apsaimniekošana (Management of Latvian forests). Rīga: 'Liesma', 116 lpp. (in Latvian)

10. Latvian Forest Register. (2018). Database.

11. Meža likums (Law on Forests). (2000). Latvijas Vēstnesis, Nr. 98/99 (2009/2010). Retrieved February 26, 2019, from https://www.vestnesis.lv/ta/id/2825-meza-likums. (in Latvian)

12. Meža statistikas CD (Forest Statistics CD). (2018). Retrieved January 5, 2019, from http://www.vmd.gov. lv/valsts-meza-dienests/statiskas-lapas/publikacijas-un-statistika/meza-statistikas-cd?nid=1809\#jump. (in Latvian) 
13. Millennium Ecosystem Assessment. (2005). Ecosystems and Human Well-being: Synthesis. Island Press, Washington, DC, $155 \mathrm{p}$.

14. Ministry of Agriculture Republic of Latvia. (2019). Meža un meža zemes platības Latvijā (Forest and forestland area in Latvia). Retrieved February 26, 2019, from https://www.zm.gov.lv/mezi/statiskas-lapas/ nozares-informacija/meza-resursi?nid=1086\#jump. (in Latvian)

15. Satterfield, T., Gregory, R., Klain, S., Roberts, M., \& Chan, K.M. (2013). Culture, intangibles and metrics in environmental management. Journal of Environmental Management. 117, 103-114.

16. Shvidenko, A., Barber, C.V., Persson, R., Gonzalez, P., Hassan, R., Lakyda, P., McCallum, I., Nilsson, S., Pulhin, J., van Rosenburg, B., \& Scholes, B. (2005). Forest and Woodland Systems. In: Ecosystems and Human Well-being: Current State and Trends, Vol. 1, Island Press, pp. 585-621.

17. TEEB. (2010). The Economics of Ecosystems and Biodiversity: Mainstreaming the Economics of Nature: A synthesis of the approach, conclusions and recommendations of TEEB.

18. United Nations (1992). Report of the United Nations Conference on Environment and Development, Annex III Non-legally binding authoritative statement of principles for a global consensus on the management, conservation and sustainable development of all types of forests, Rio de Janeiro, 3-14 June 1992 